Sains Malaysiana 48(5)(2019): 1083-1095

http://dx.doi.org/10.17576/jsm-2019-4805-17

\title{
Oxidative Status in Bipolar Disorder (BD) and Its Correlation with Age, Gender and Body Mass Index (BMI)
}

(Status Oksidatif dalam Gangguan Bikutub dan Kaitannya dengan Umur, Jantina dan Indeks Jisim Tubuh)

\author{
JACLYN TAN Ai Chin, GeEtha GunASEKaran, MOHD Hanafi AHMAD DAMANHURI, \\ CHAN LAI FONG, LOO JIANN LIN \& GOON JO AAN*
}

\begin{abstract}
Bipolar disorder (BD) is a chronic psychiatric illness which molecular foundations have yet to be elucidated. Oxidative stress appears to be a promising field of study to understand the formation of this disease in molecular level. The objective was to investigate the oxidative status of $B D$ and its association with age, gender and body mass index (BMI). A crosssectional study was conducted in a tertiary university hospital in Cheras, Malaysia on 55 patients with BD diagnosed using Mini Neuropsychiatric Interview (MINI). Peripheral markers of oxidative stress which include superoxide dismutase (SOD), glutathione peroxidise (GPX), catalase (CAT), malondialdehyde (MDA) and DNA damage were examined in subjects with $B D$ $(\mathrm{n}=55)$ and compared to healthy controls $(\mathrm{n}=28)$. BD patients had significantly higher concentrations of MDA compared to healthy controls $(\mathrm{p}<0.001)$. Concentration of MDA was significantly higher in BD patients aged 40 and above compared to those aged 39 years and below $(\mathrm{p}<0.05)$. The concentration of MDA did not show significant difference between male and female BD patients, likewise between patients with BMI below and above 25. The percentage of normal DNA in healthy controls was significantly higher than that of $B D$ patients $(\mathrm{p}<0.001)$, while percentage of mildly and severely damaged DNA in BD patients was significantly higher than that of healthy controls (mildly damaged: $\mathrm{p}<0.001$; severely damaged: $\mathrm{p}<0.001)$. The severity of DNA damage in the BD patients was similar when compared between age, gender and BMI. SOD activity of $B D$ patients was found to be comparable to that of healthy subjects as well as when compared between gender and age, but was significantly lower in subjects with BMI above $25(\mathrm{p}<0.05)$. CAT activity was significantly higher in BD patients compared to controls $(\mathrm{p}<0.001)$, while no significant difference was found when compared between gender, age and BMI. GPX activity did not show significant difference when compared between BD and healthy controls, gender, age and BMI. Multiple linear regression analysis showed that the percentage of normal DNA increases with age in BD patients $(\mathrm{p}<0.001)$, while the percentage of damaged DNA decreases with age (mildly damaged: $\mathrm{p}<0.002 ;$ severely damaged: $\mathrm{p}<0.001)$. Percentage of normal and damaged DNA are not significantly correlated with BMI, while all antioxidative enzymes (SOD, GPX, CAT) and MDA concentration did not show significant correlation with age and BMI. In conclusion, age and BMI are associated with the oxidative status of BD patients regardless of gender.
\end{abstract}

Keywords: Bipolar disorder; catalase; glutathione peroxidase; malondialdehyde; superoxide dismutase

\section{ABSTRAK}

Gangguan bikutub (BD) ialah sejenis penyakit psikiatrik kronik kerana asas kejadian molekulnya masih belum ditentukan. Tekanan oksidatif adalah bidang yang berpotensi dikaji dalam memahami kejadian penyakit ini pada peringkat molekul. Objektif kajian adalah untuk menentukan status oksidatif pada pesakit BD dan kaitannya dengan umur, jantina dan indeks jisim tubuh (BMI). Satu kajian keratan rentas telah dijalankan di sebuah hospital universiti pengajian tinggi di Cheras, Malaysia ke atas 55 pesakit BD yang didiagnos menggunakan Mini Neuropsychiatric Interview (MINI). Aktiviti enzim superoksida dismutase (SOD), glutation peroksida (GPX), katalase (CAT), kepekatan malondialdehid (MDA) dan kerosakan $D N A$ dibandingkan antara subjek dengan $B D(\mathrm{n}=55)$ dan kawalan sihat $(\mathrm{n}=28)$. Pesakit BD mempunyai kepekatan MDA yang lebih tinggi secara signifikan berbanding kepada kawalan sihat $(\mathrm{p}<0.001)$. Kepekatan MDA adalah lebih tinggi bagi pesakit BD berumur 40 ke atas berbanding kepada yang berumur 39 dan ke bawah (p<0.05). Kepekatan MDA tidak menunjukan perbezaan yang signifikan apabila dibandingkan antara jantina, sama juga antara pesakit dengan BMI kurang atau lebih daripada 25. Peratus DNA normal pada kawalan sihat adalah lebih tinggi secara signifikan berbanding kepada pesakit BD ( $\mathrm{p}<0.001)$, manakala peratus DNA rosak ringan dan rosak teruk pada pesakit BD adalah lebih tinggi secara signifikan berbanding kepada kawalan sihat (rosakan DNA ringan: $\mathrm{p}<0.001$; kerosakan DNA teruk: $\mathrm{p}<0.001$ ). Tahap kerosakan DNA dalam pesakit BD adalah lebih kurang sama apabila dibandingkan antara umur, jantina dan BMI. Aktiviti SOD pesakit BD adalah lebih kurang sama dengan subjek sihat dan apabila dibandingkan antara jantina dan umur, tetapi adalah lebih rendah secara signifikan pada subjek dengan BMI lebih daripada 25 (p<0.05). Aktiviti CAT adalah lebih tinggi secara signifikan dalam pesakit BD berbanding kumpulan kawalan $(\mathrm{p}<0.001)$, manakala tiada perbezaan signifikan antara jantina, umur dan BMI. Aktiviti GPx tidak menunjukkan perbezaan signifikan apabila dibandingkan antara pesakit BD dan subjek sihat, jantina, umur dan BMI. Analisis regresi linear berganda menunjukkan peratus DNA 
normal meningkat dengan umur $(\mathrm{p}<0.001$ ), manakala peratus DNA rosak menurun dengan umur (kerosakan DNA ringan: $\mathrm{p}<0.002$; kerosakan DNA teruk: $\mathrm{p}<0.001$ ). Peratus DNA normal dan rosak tidak menunjukkan korelasi signifikan dengan BMI, manakala semua enzim oksidatif (SOD, GPX, CAT) dan kepekatan MDA tidak menunjukkan korelasi signifikan dengan umur dan BMI. Secara kesimpulannya, umur dan BMI adalah berkaitan dengan status oksidatif pesakit BD tanpa mengira jantina.

Kata kunci: Gangguan bikutub; glutation peroksidase; katalase; malondialdehid; superoksida dismutase

\section{INTRODUCTION}

Bipolar disorder (BD) is a chronic psychiatric illness, involving mood swings that range from extreme high (mania) to extreme low (depression) that occur with distinctive beginnings and ends, but may arise together (Elhaik \& Zandi 2015). Based on a large cross sectional study over 11 countries in the Americas, Europe and Asia, the overall lifetime prevalence of bipolar spectrum disorders was documented as $2.4 \%$ (Merikangas et al. 2011). This disease represents a complex interplay of genes and environment (Uher 2014). It is found that life expectancy of individuals suffering from this illness is shortened by 10 to 15 years not just because of an increased suicide rate but also by the presence of medical comorbidities such as obesity, diabetes, cardiovascular disease, and other metabolic conditions (Laursen 2011; Merikangas et al. 2007; Swartz \& Fagiolini 2012).

Despite the discovery of this manic-depressive illness for nearly a century (Kraepelin 1921), the molecular foundations for this disease progression are still unclear. Several systemic alterations including increased inflammatory markers, oxidative stress, DNA damage and reduced neurotrophic factors has been proposed to contribute to the pathophysiology of bipolar disorder (Andreazza et al. 2008; Fernandes et al. 2011; O'brien et al. 2006). Among these, oxidative stress seems to be a promising lead in biological alterations in BD (Frey et al. 2013; Grande et al. 2012).

Oxidative stress occurs when the pro-oxidant levels in cells overwhelm the antioxidant capacity. This happens when there is an overproduction of free radicals or a reduction in antioxidant defence systems or when both circumstances occur at once. Free radicals play a role in physiological processes when kept in controlled conditions by antioxidant systems. However, an imbalance between the production of free radicals and insufficient decomposition by the endogenous antioxidant system can lead to oxidative stress which threatens the normal functionality of proteins, lipids, and nucleic acids (Sarangarajan et al. 2017).

Superoxide dismutase (SOD), catalase (CAT) and glutathione peroxidase (GPx) are the main intracellular antioxidant enzymes which form an antioxidant defence system against radical mediated damage. SOD is the first detoxification enzyme against reactive oxygen produced in cells. SOD dismutates superoxide radical to hydrogen peroxide $\left(\mathrm{H}_{2} \mathrm{O}_{2}\right)$, which is further converted to $\mathrm{H}_{2} \mathrm{O}$ by CAT and GPX. Deficiency of SOD enzyme may increase cell membrane peroxidation, neurodegeneration, weakened immune response and myocardial injury thus leading to vascular injury, neurological diseases, inflammatory conditions and cardiovascular diseases (Ighodaro \& Akinloye 2017). CAT and GPx function to limit $\mathrm{H}_{2} \mathrm{O}_{2}$ concentration in cells which is crucial for the regulation of signaling in cell proliferation, cell death, carbohydrate metabolism, mitochondrial function, and platelet activation and maintenance of normal thiol redox-balance (Dröge 2002). Increased oxidative stress due to deficiency of CAT may contribute to the manifestation of diabetes while deficiency of GPx is suggested to accelerate diabetesassociated atherosclerosis (Góth \& Nagy 2013; Lewis et al. 2007).

Due to the fact that the brain is only $2 \%$ of total body weight while metabolizing $20 \%$ of total body oxygen, it is particularly vulnerable to the production of reactive oxygen species (ROS) (Kim et al. 2015). Bipolar disorder is associated with decreased glutathione levels, resulting in increased oxidative stress (Brown et al. 2014; Rosa et al. 2014). N-Acetylcysteine (NAC) has been used as an adjunct therapy in bipolar disorder to increase glutathione levels and reduce oxidative stress in the brain (Choy et al. 2010; Dean et al. 2009). Two previous clinical trials on NAC for bipolar disorder have shown significant effects on depressive symptoms (Berk et al. 2011, 2008).

Even though oxidative stress markers have been studied in BD, conflicting results are still being reported. Oxidative damage to DNA, RNA, proteins, and lipids in BD subjects are found in some studies (Andreazza et al. 2007; Brown et al. 2014; Che et al. 2010), while others report of altered levels of some antioxidant enzymes (Brown et al. 2014; Kuloglu et al. 2002; Ozcan et al. 2004). Moreover, most if not all of these studies have been conducted on Caucasian subjects and no studies have been done on Asian populations at best of our knowledge (Andreazza et al. 2007; Che et al. 2010; Kuloglu et al. 2002; Ozcan et al. 2004; Savas et al. 2006).

Bipolar disorder usually appears in adolescence or early adulthood, but can emerge in childhood or onset later in adulthood. In Malaysia, the mean age of onset is between 17 and 21 years (Malaysian Psychiatric Association 2007). Early and late onset bipolar disorder differ in clinical expression, where those with early onset have more manic relapses but slower relapse frequency than those with late onset (Haouala et al. 2016). Patients with early onset also demonstrated more psychotic characteristics than late onset bipolar disorder patients (Haouala et al. 2016; Mcglashan 1988), and are associated with an elevated morbid risk among relatives. Because of the increasing attention of the role of oxidative stress in the pathophysiology of $\mathrm{BD}$, it is 
interesting to explore the oxidative stress between early and late onset of this illness. Further insights regarding oxidative stress in BD with relevance to age may potentially shed some light towards the formation of this disease. In addition, these findings may also prove to be useful for future clinical and genetic studies for this illness.

In terms of gender, existing literatures proposed that it plays an important role in the clinical presentation of bipolar disorder (BD) (Diflorio \& Jones 2010). Studies have found that comorbid anxiety (Benedetti et al. 2007) and eating disorders (Diflorio \& Jones 2010) are more common in women with $\mathrm{BD}$, while men are more prone to comorbid alcohol or drug abuse (Kawa et al. 2005; Kessing 2004; Ringen et al. 2008). The predominance of depressive and anxious symptomatology in women with BD correlates with validated findings of increased prevalence of affective morbidity in women (Kessler et al. 1993). Some studies have shown that in recent years, several pathologies involving oxidative imbalances have been underestimated in women and that those diseases progress differently by gender (Malorni et al. 2007). Furthermore, the clinical features, phenomena and evolution of BD greatly differ between men and women, particularly the course of illness, quality of life and psychosocial functioning of patients (Miquel et al. 2011; Nivoli et al. 2011).

$\mathrm{BD}$ has also been found to be associated with increased morbidity and mortality due to general medical conditions such as metabolic syndrome, cardiovascular diseases and obesity (Kupfer 2005; Roshanaei-Moghaddam \& Katon 2009). Obesity rates are found to be higher than normal across an array of psychiatric disorders including anxiety disorder, major depressive disorder, schizophrenia as well as bipolar disorder (Lopresti \& Drummond 2013). Although this phenomenon is acknowledged in mental health studies and treatment, an understanding of their bi-directional relationship is still lacking. With the similarities in their dysregulated pathways in both obesity and bipolar disorder, the relationship between these two phenomenon in terms of oxidative status could show novel insights, subsequently help to fine tune interventions in complementing treatment to enhance mental health outcomes in BD patients.

Age, gender and body mass index (BMI) effects on oxidative status of BD are still limited and the influence of these factors towards BD is not fully understood. In this present study, we aim to determine the oxidative status among BD patients compared to healthy controls. The BD subjects were subdivided based on age, gender and body mass index (BMI) to determine if these variables influence the oxidative status of those individuals, leading to differences in BD vulnerability.

\section{MATERIALS AND METHODS}

\section{SUBJECTS RECRUITMENT}

The protocol for this study was approved by the Ethical Committee of Universiti Kebangsaan Malaysia (UKM1.5.3.5/244/GUP-2014-048). Study participants that includes 55 patients with BD and 27 healthy controls, age ranging from 19 years old to 74 years old were recruited from both inpatient and outpatient settings in University Kebangsaan Malaysia Medical Centre (UKMMC) between December 2015 and November 2017. The diagnosis of BD was confirmed based on the M.I.N.I. Neuropsychiatric Interview (MINI 7.0) (Van Vliet \& De Beurs 2007). All subjects had given written informed consent before participating in the study. Exclusion criteria were the presence of alcohol dependence, substance misuse disorder, smoker, and terminal medical illness. Additional exclusion criteria for controls were the presence of lifetime psychiatric diagnoses as well as first and second grade relationship to relatives with psychiatric disorders.

\section{ANTIOXIDANT ENZYMES}

Blood samples of $10 \mathrm{~mL}$ were collected in heparinized tubes for the analysis of superoxide dismutase (SOD), glutathione reductase (GPx), and catalase (CAT) activities as well as comet assay and malondialdehyde (MDA) concentrations. Fresh whole blood was used for comet assay while the rest of the blood samples were centrifuged to separate the red blood cells from the plasma. The plasma layer was transferred into eppendorf tubes and the remaining $\mathrm{RBC}$ pellet were washed before being stored at $-80^{\circ} \mathrm{C}$ freezer until time of analysis.

Measurement of SOD activity was performed according to Beyer and Fridovich (1987). Hemosylate prepared was added to $1 \mathrm{~mL}$ of substrate solution, and the mixture was reacted with $10 \mu \mathrm{L}$ riboflavin $(0.117 \mathrm{mM})$ in a brightly lit aluminium foil lined box for $7 \mathrm{~min}$. A control tube in which phosphate buffer was used in place of the sample was run in parallel, and the absorbance was measured at $560 \mathrm{~nm}$. One unit of SOD was defined as the amount of enzyme that would inhibit the rate of reduction of nitro blue tetrazolium by $50 \%$ at $25^{\circ} \mathrm{C}$ at $\mathrm{pH} 7.8$.

Measurement of GPx activity was determined based on the method published by Paglia and Valentine (1967). Hemolysates were first diluted with $0.8 \mathrm{~mL}$ distilled water and then mixed with $1 \mathrm{~mL}$ of cyanmethemoglobin reagent before adding to a substrate mixture. $\mathrm{H}_{2} \mathrm{O}_{2}(2.2 \mathrm{mM})$ was added into the reaction mixture and a change in absorbance for $5 \mathrm{~min}$ at $340 \mathrm{~nm}$ was recorded. For control, the same procedure was performed by replacing the hemolysate with distilled water. One unit of GPx was defined as the amount of enzyme that would oxidize $1 \mu$ mole NADPH to NADP ${ }^{+}$ per min at $25^{\circ} \mathrm{C}$ and $\mathrm{pH} 8.0$.

CAT activity was determined according to the method published by Aebi (1984). The reaction was initiated with the addition of $\mathrm{H}_{2} \mathrm{O}_{2}(30 \mathrm{mM})$ to the enzyme solution. The change in absorbance was read against a blank containing $1 \mathrm{~mL}$ phosphate buffer instead of $\mathrm{H}_{2} \mathrm{O}_{2}$ and $2 \mathrm{~mL}$ enzyme solution. One unit of CAT was defined as the amount of enzyme that would decompose $1 \mu$ mole $\mathrm{H}_{2} \mathrm{O}_{2}$ per second at $25^{\circ} \mathrm{C}$ and $\mathrm{pH} 7.0$.

Haemoglobin content of all hemolysates used for SOD, GPx and CAT analyses were measured by using a 
haemoglobin assay kit supplied by Eagle Diagnostic (USA) based on manufacturer's guide.

\section{DNA DAMAGE}

DNA damage determination was carried out based on the comet assay protocol published by Singh et al. (1994). To prepare the slides, $5 \mu \mathrm{L}$ fresh whole blood with $80 \mu \mathrm{L}$ $0.6 \%$ low-melting-point agarose (LMA) was sandwiched between a layer of $0.6 \%$ normal melting-point agarose (NMA) on a frosted slide. Then, the slides were immersed in lysis solution for $1 \mathrm{~h}$ at $4^{\circ} \mathrm{C}$ to release the DNA. Next, the DNA was denatured by placing the slides in an alkaline bath to enable the expression of alkali-labeled DNA damage for $20 \mathrm{~min}$ at $4^{\circ} \mathrm{C}$. Electrophoresis was conducted for $20 \mathrm{~min}$ at $4^{\circ} \mathrm{C}$ using $25 \mathrm{~V}$ and $300 \mathrm{~mA}$. After electrophoresis, the slides were neutralized using 0.4 M Tris-base by a dropwise manner. Lastly, the DNA was stained with ethidium bromide $(20 \mu \mathrm{g} / \mathrm{mL})$ and before being analyzed using a fluorescence microscope. A total of 500 cells were analyzed for each subject, and the degree of DNA damage was categorized into normal, mildly damaged, and severely damaged DNA based on the microscopic observation of tail length of each cell shown in Figure 1.

\section{MALONDIALDEHYDE (MDA)}

Plasma MDA concentration was determined using the method published by Pilz et al. (2000). MDA standard curve was first prepared according to the manufacturer's guide. For alkaline hydrolysis of protein-bound MDA, 50 $\mu \mathrm{L}$ of $6 \mathrm{M}$ sodium hydroxide was added to $0.25 \mathrm{~mL}$ of plasma, and the sample was incubated for $1 \mathrm{~h}$ in a $60^{\circ} \mathrm{C}$ water bath. The hydrolyzed sample was acidified with
$0.125 \mathrm{~mL}$ of $35 \%$ perchloric acid. After centrifugation at $3000 \mathrm{rpm}, 0.25 \mathrm{~mL}$ of supernatant was mixed with $25 \mu \mathrm{L}$ 2,4-dinitrophenylhydrazine (DNPH) solution and incubated for $10 \mathrm{~min}$. A $30 \mu \mathrm{L}$ volume of the reaction mixture was directly injected into the high performance liquid chromatography system (HPLC). Analytical HPLC separations were performed with a variable wavelength ultraviolet detector operated at $310 \mathrm{~nm}$ on a $3.9 \times 150 \mathrm{~mm}$ $\mathrm{C}_{18}$ column.

\section{STATISTICAL ANALYSIS}

Statistical analysis was performed using SPSS 23.0 (IBM, Armonk, USA). The results are expressed as means \pm $\mathrm{SD}$, and $p<0.05$ was considered statistically significant. All parameters which are SOD, GPx, CAT activities, MDA concentration and percentage of DNA damage were tested for normality distribution. Non-parametric Mann-Whitney test was used for the analysis of SOD activity as the subjects were not normally distributed in BD and control groups. All other parameters were found to be normally distributed and analysed using parametric tests. Independent-samples t-test was used to determine the significance of differences in the measured parameters based on type of subject, while two-way ANOVA was used to determine the significance of differences in the measured parameter according to gender, age and BMI category between BD and healthy controls. Three-way ANOVA was used to analyse the results of comet assay where levels of normal, mildly and severely damaged DNA were compared between BD and healthy subjects grouped according to gender, age and BMI. Bivariate correlation was employed to determine the influence of age and BMI on MDA concentration as well as normal and damaged DNA.

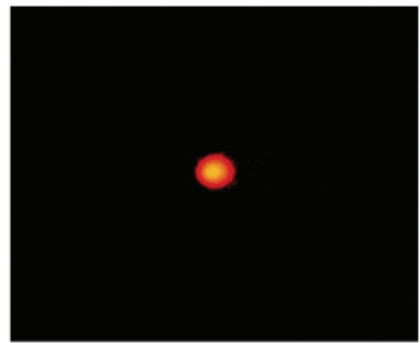

Score 0

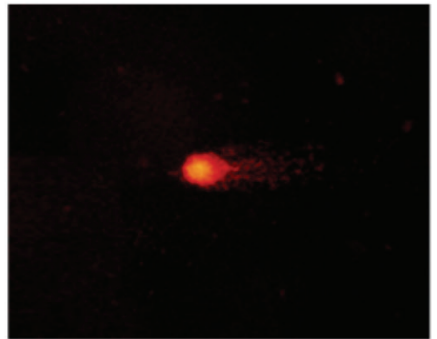

Score 1

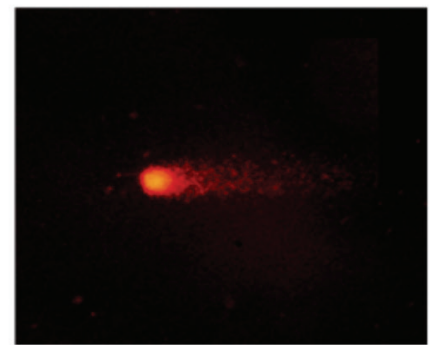

Score 2

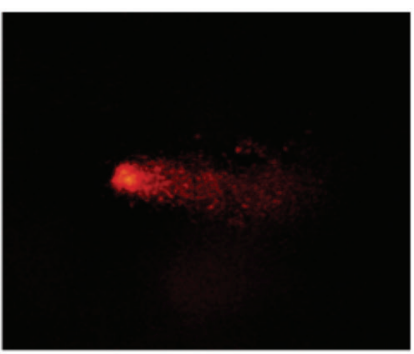

Score 3

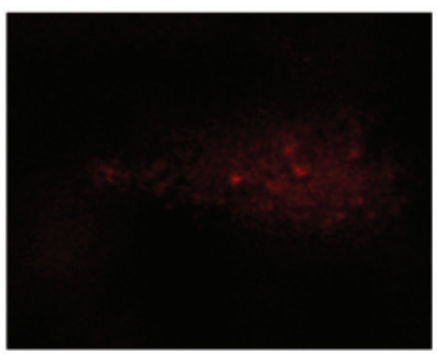

Score 4

FIGURE 1. Comet assay images of DNA at different degrees of damage. Score 0 is normal DNA, scores 1 and 2 are mildly damaged DNA while scores 3 and 4 are severely damaged DNA 


\section{RESULTS}

The demographic data of the study participants with BD and healthy controls are shown in Table 1. Due to the limitation of research funding, subjects that were successfully recruited were not age- and sex-matched with cases. The average age for subjects with BD was generally older as compared to the controls while the number of females were more than males in $\mathrm{BD}$.
There were no significant differences in SOD activity when compared between male and female BD subjects (Figure 2). Either male nor female BD subjects had differences in the activity of SOD when compared to their respective controls. BD subject aged $\geq 40$ had similar SOD activity to those aged $\leq 39$. Comparisons within the similar age groups also showed no significant differences in the activity of SOD. However, SOD activity was significantly higher in BD patients with BMI $\leq 24.9$ compared to $\geq 25$.

TABLE 1. Demographic data of participants

\begin{tabular}{lcccc}
\hline & & BD & \multicolumn{2}{c}{ Control } \\
\cline { 2 - 5 } & $\mathrm{M}$ & $\mathrm{F}$ & $\mathrm{M}$ & $\mathrm{F}$ \\
\hline Subjects (n=83) & 19 & 36 & 13 & 15 \\
Age (years) & $46.1 \pm 16.8$ & $40.3 \pm 12.9$ & $35.8 \pm 10.9$ & $30.7 \pm 6.9$ \\
BMI (kgm ${ }^{-2}$ ) & $23.6 \pm 3.5$ & $27.6 \pm 5.5$ & $23.2 \pm 3.4$ & $23.4 \pm 5.1$ \\
\hline
\end{tabular}

BMI, body mass index

A
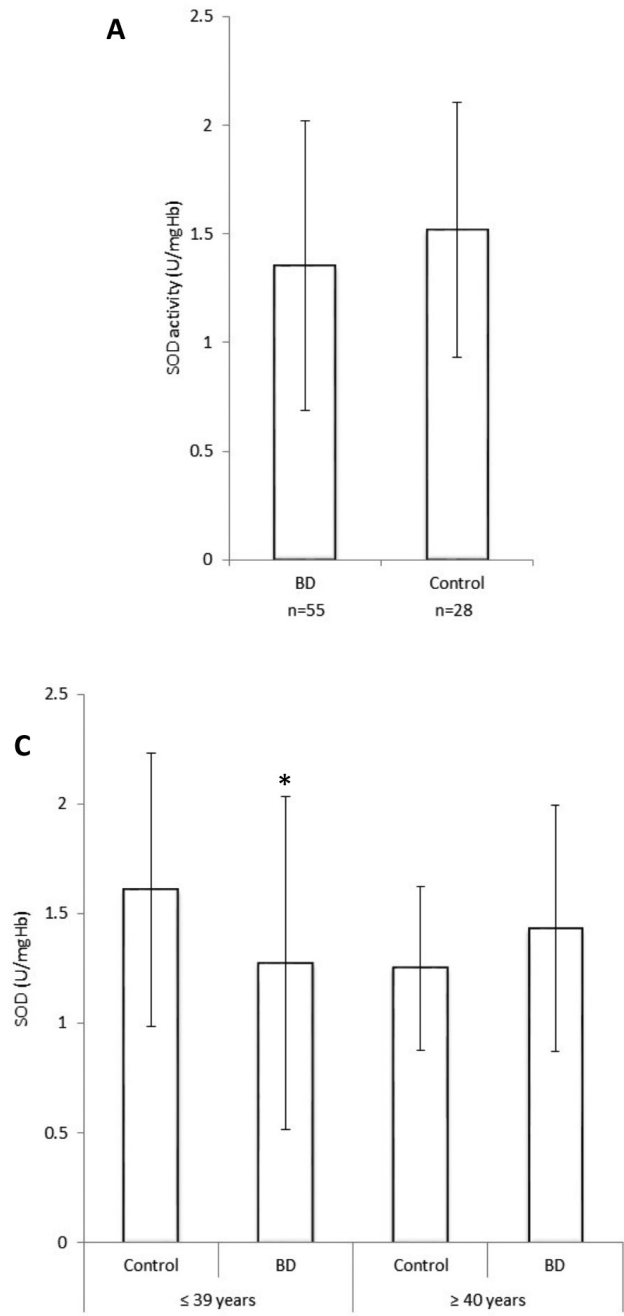

B
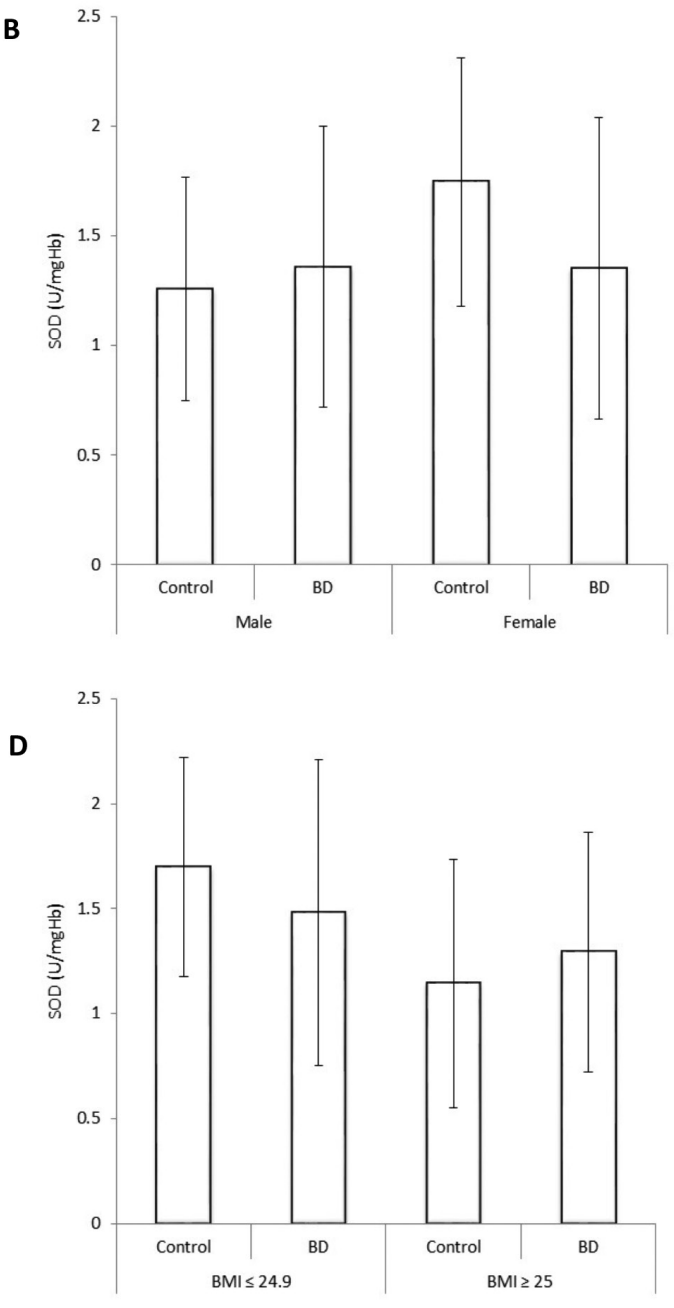

FIGURE 2. SOD activity in BD patients and normal controls. (A) SOD activity was comparable between BD patients and controls, (B) SOD activity were similar between males and females BD patients as well as between patients and controls of the same gender, (B) SOD activity did not show significant difference between BD patients aged $\leq 39$ and $\geq 40$ as well as between patients and controls of the same age group, (C) SOD activity was significantly higher in BD patients with BMI $\leq 24.9$ compared to BMI $\geq 25$ ( $<<0.05$ ).

Comparison between BD patients and controls within the same BMI group showed no significant differences 
The activity of SOD was similar between BD and control when comparison was made within the same BMI groups.

As for CAT activity, significantly higher enzyme activity was found in BD patients compared to controls (Figure 3). Further grouping by gender showed that CAT activity was comparable between male and female BD patients. In addition, no significant differences were found in the activity of CAT when comparison was made between $\mathrm{BD}$ and control subjects within a single gender. The activity of this enzyme was also similar between BD patients aged $\leq 39$ and $\geq 40$. Patients within the same age groups had comparable CAT activity to the controls. Overweight BD patients with BMI $\geq 25$ had similar level of CAT activity compared to BD patients with BMI $\leq 24.9$. Patients within the same BMI groups also had comparable levels of CAT activity to the controls.
BD patients had no significant differences in GPX activity compared with the controls (Figure 4). The activity of this enzyme also showed no significant differences when comparisons were made between BD patients and control grouped according to gender, age and BMI was found when compared between all groups. Similarly, no marked differences were found when BD patients were compared to the controls within the same gender, age group and BMI group.

BD patients had significantly higher concentrations of MDA compared to healthy controls $(p<0.001)$ (Figure 5). The concentration of MDA was significantly higher in BD patients aged $\geq 40$ years compared to those aged $\leq 39$ years $(p<0.05)$. No significant differences were found when comparison was made between BD patients and controls grouped according to different age and BMI categories respectively.
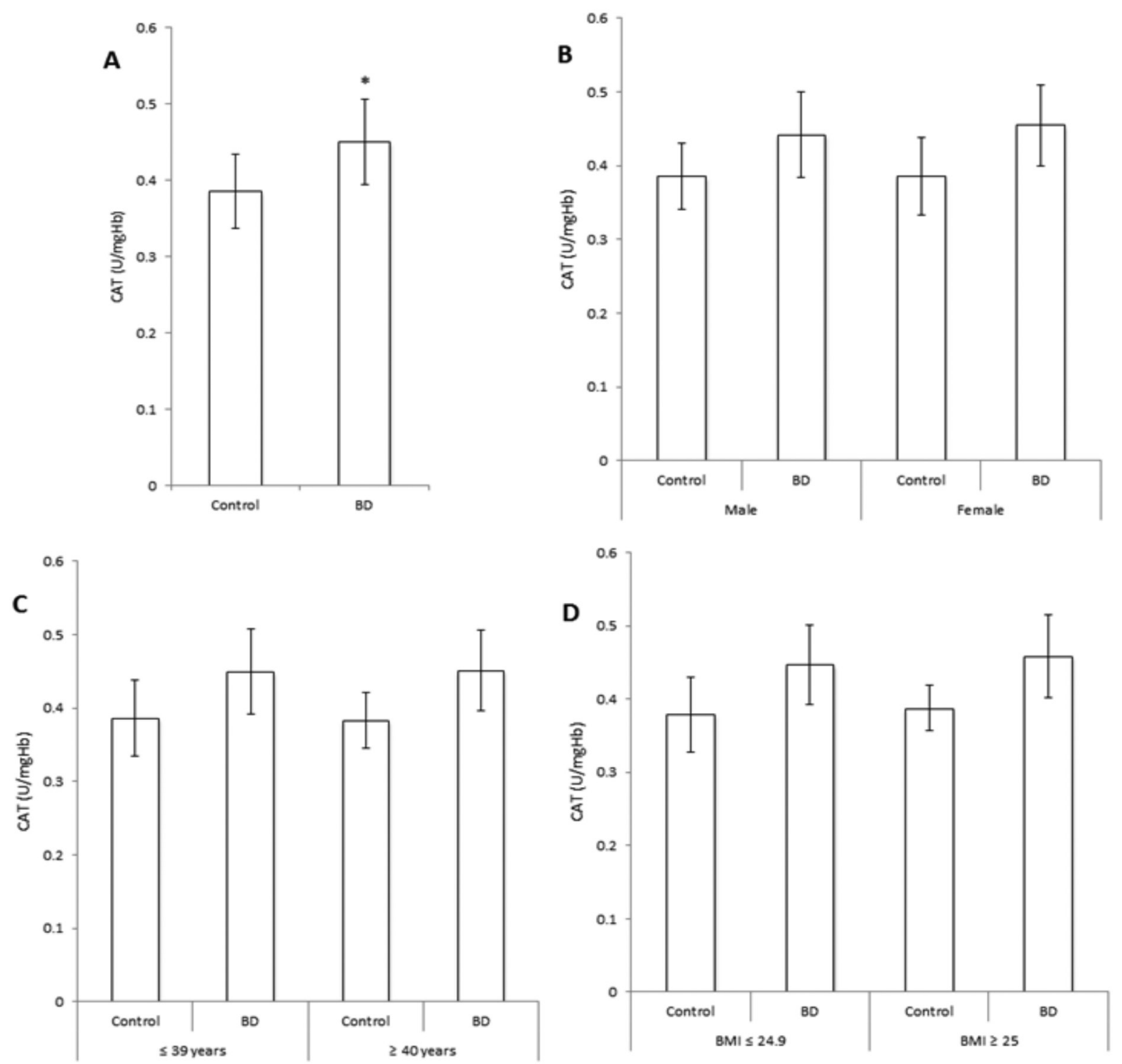

FIGURE 3. CAT activity in BD patients and normal controls. (A) CAT activity was significantly higher in BD patients compared to controls $(p<0.001)$, (B) CAT activity did not show significant differences between male and female BD patients as well as between BD and controls within a similar gender, (C) CAT activity did not show significant difference between ages $\leq 39$ and $\geq 40$ years in BD patients. The enzyme activity was comparable between control and BD patients in either age groups. (D) CAT activity did not show significant difference between BMI $\leq 24.9$ and $\geq 25$ among BD patients and controls. The two groups of subjects had no significant differences in CAT activity when compared within the same BMI category 

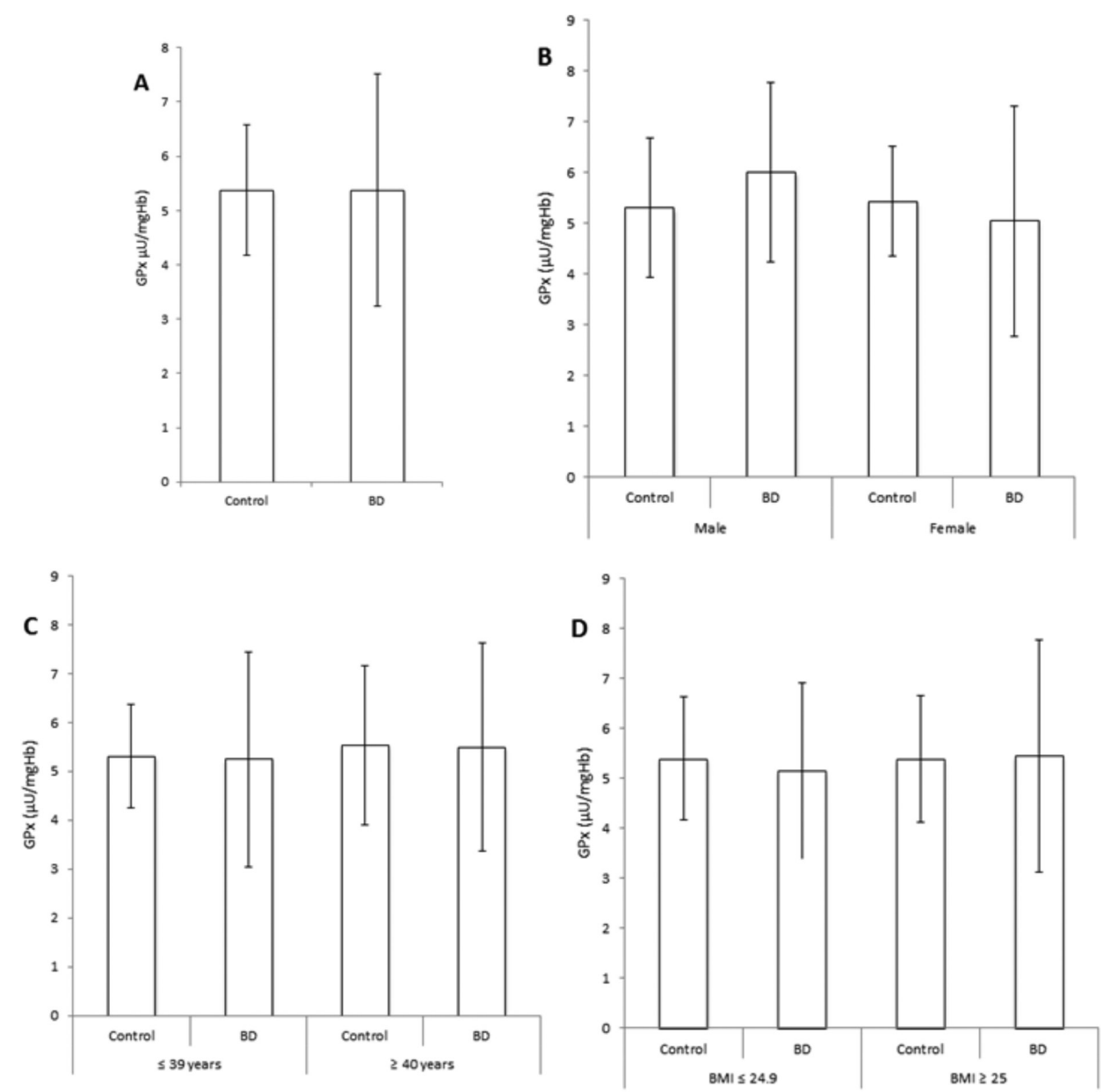

FIGURE 4. GPx activity in BD patients and normal controls. (A) GPx activity did not show significant difference between BD patients and controls, (B) GPx activity did not show significant differences between genders as well as between BD patients and controls of a similar gender, (C) GPx activity did not show significant differences between BD patients aged $\leq 39$ and $\geq 40$ years. The enzyme activity was similar between BD patients and controls in either age groups, (D) GPx activity did not show significant difference between BD patients with BMI

Percentage of normal DNA was significantly lower in $\mathrm{BD}$ patients compared to controls $(p<0.001)$, while percentage of mildly and severely damaged DNA were significantly higher in BD subjects compared to controls (mildly damaged: $\mathrm{p}<0.001$; severely damaged: $p<0.001$ ) (Figure 6). Conversely, percentage of normal, mildly and severely damaged DNA were found to be comparable between $\mathrm{BD}$ and controls when they were grouped according to different genders, age and BMI categories, respectively. In addition, no significant differences were noted within BD patients or the healthy controls when they were grouped respectively as mentioned.

Statistical analysis was first performed to determine the correlation of MDA concentration to age and BMI, percentage of normal DNA to age and BMI as well as percentage of damaged DNA with age and BMI in BD patients. The results showed that there was no significant correlation between the concentration of MDA with age and BMI. Percentage of normal DNA was positively correlated with age $(r=0.346)$ (Figure 7), while percentage of damaged DNA was negatively correlated with age $(r=-0.346)$ (Figure 8$)$.

\section{DISCUSSION}

The average age of BD subjects recruited in this study was older as compared to the healthy controls. Nevertheless, the BD subjects and healthy controls were all below 50 years of age. Previous studies had grouped healthy older adults aged between 35-49 years old and compared their oxidative stress level to older adults aged above 50 where a significant higher stress level was observed in the later (Chin et al. 2011, 2008). These studies also indicated that younger adults within 35-49 years old had lower oxidative stress level which were unaffected by antioxidant supplementation. Hence, it is assumed that the differences in age between BD and control groups should have insignificant effects on the level of oxidative stress markers measured in this study.

The human brain is a highly oxygenated organ that utilizes about one-fifth of the body's total oxygen requirement making it highly susceptible to oxidative damage (Kuloglu et al. 2002). A number of studies have reported increased lipid peroxidation and altered antioxidant enzymes activities in individuals diagnosed 

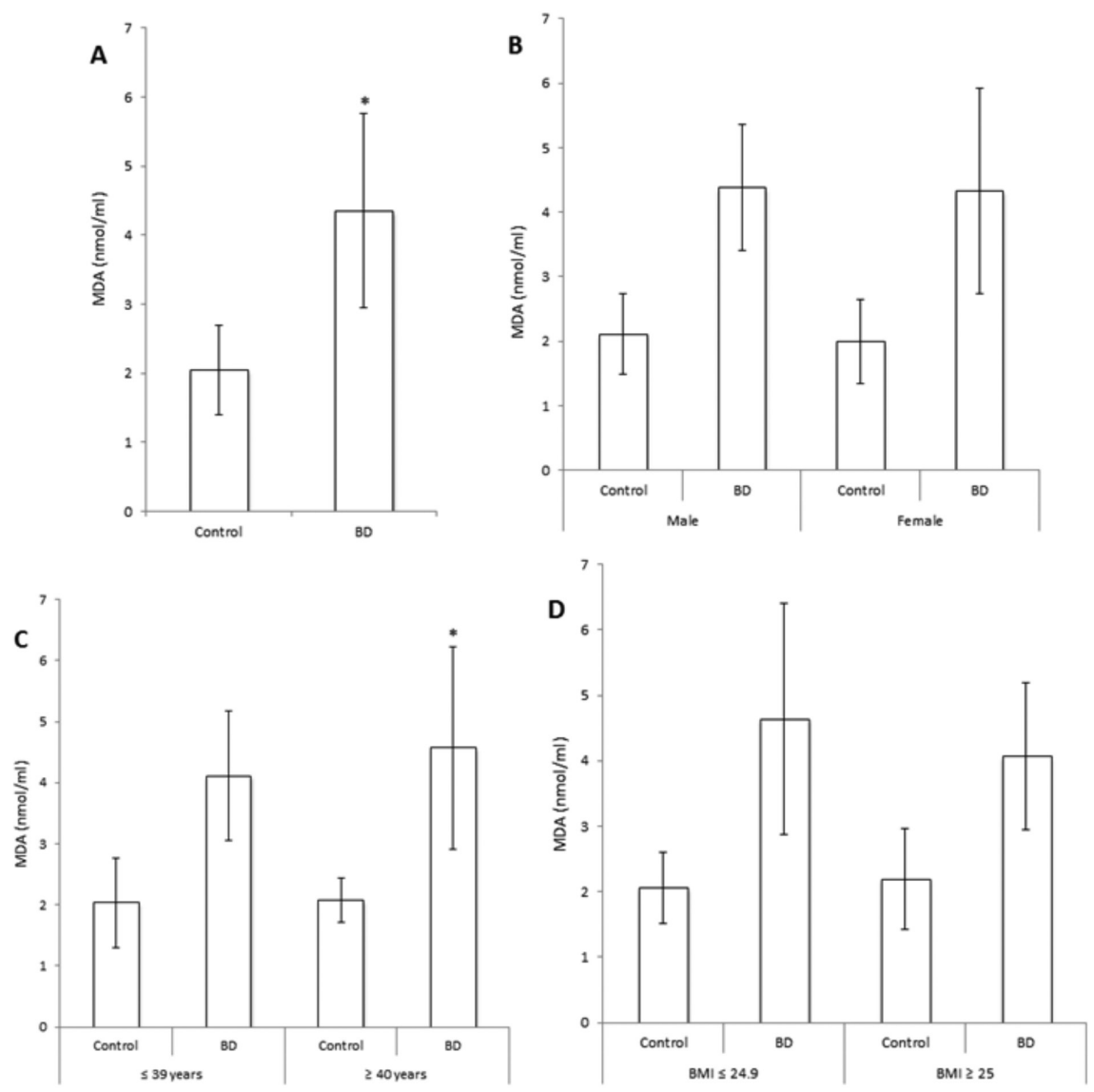

FIGURE 5. MDA concentration in BD patients and normal controls. (A) MDA concentration was significantly higher in BD patients compared to controls $(p<0.001)$. MDA was significantly higher in BD patients aged $\geq 40$ years compared to those aged $\leq 39$ years $(p<0.05)$, (B) MDA concentration did not show significant differences when compared between genders in BD patients and well as in controls, (C) MDA concentration was significantly higher in BD patients aged $\geq 40$ years compared to $\leq 39$ yeras, (D) MDA concentration did not show significant difference between BD patients and control in different BMI categories

with BD (Kapczinski et al. 2011; Kuloglu et al. 2002; Ozcan et al. 2004; Ranjekar et al. 2003). A meta-analysis done by Brown et al. (2014) also reported increased lipid peroxidation and elevated DNA/RNA damage in BD compared to controls.

Based on the results, SOD activity in BD was similar to that of healthy controls. This is in line with the findings of previous studies which reported of unchanged SOD activity in BD (Andreazza et al. 2008; Bengesser et al. 2015). However, SOD activity have also been reported to be higher in BD compared to healthy individuals in another study (Kuloglu et al. 2002). This discrepancy surrounding SOD activities in BD may be due to the state dependent changes in oxidant levels (Savas et al. 2006; Selek et al. 2008), where SOD activity have been reported to be higher in euthymic state compared to manic or depressed state. The unaltered activity of SOD seen in this study could be due to the lower severity of the disease as compared to previous studies. However, this hypothesis renders further investigation as the severity of BD was not assessed in our subjects and the number of patients enrolled were limited. GPx activity was also found to be similar to that of control, which agrees to the results of some previous findings
(Andreazza et al. 2008; Kuloglu et al. 2002). Due to the nature of the synergistic and interdependent properties of the antioxidative enzyme system, the action of one antioxidant enzyme may be dependent on the proper function of other members in the antioxidant defense (Bengesser et al. 2015). In this case, it is postulated that CAT compensated the dysregulation in oxidative defenses leading to its increased activity in BD. This compensatory response has also been suggested to occur in the acute phase of bipolar episodes (Kunz et al. 2008). Similarly, CAT activity has been previously found to be elevated in BD patients during depressive episodes (De Sousa et al. 2014). Lipid peroxidation markers such as MDA are products of oxidation, which express the oxidative damage of structural lipids leading to cell death (Mahadik et al. 2001). Our study noted significantly higher MDA concentrations in BD compared to control, similar to findings reported previously (Brown et al. 2014; Kuloglu et al. 2002). As the volume of lipids make up for approximately $70 \%$ of the dry weight of myelin, which is the major component of white matter, this damage may be a factor that leads the progression of BD (Brown et al. 2014). Additionally, Versace et al. (2014) have found that $59 \%$ of fractional anisotropy and $51 \%$ of 


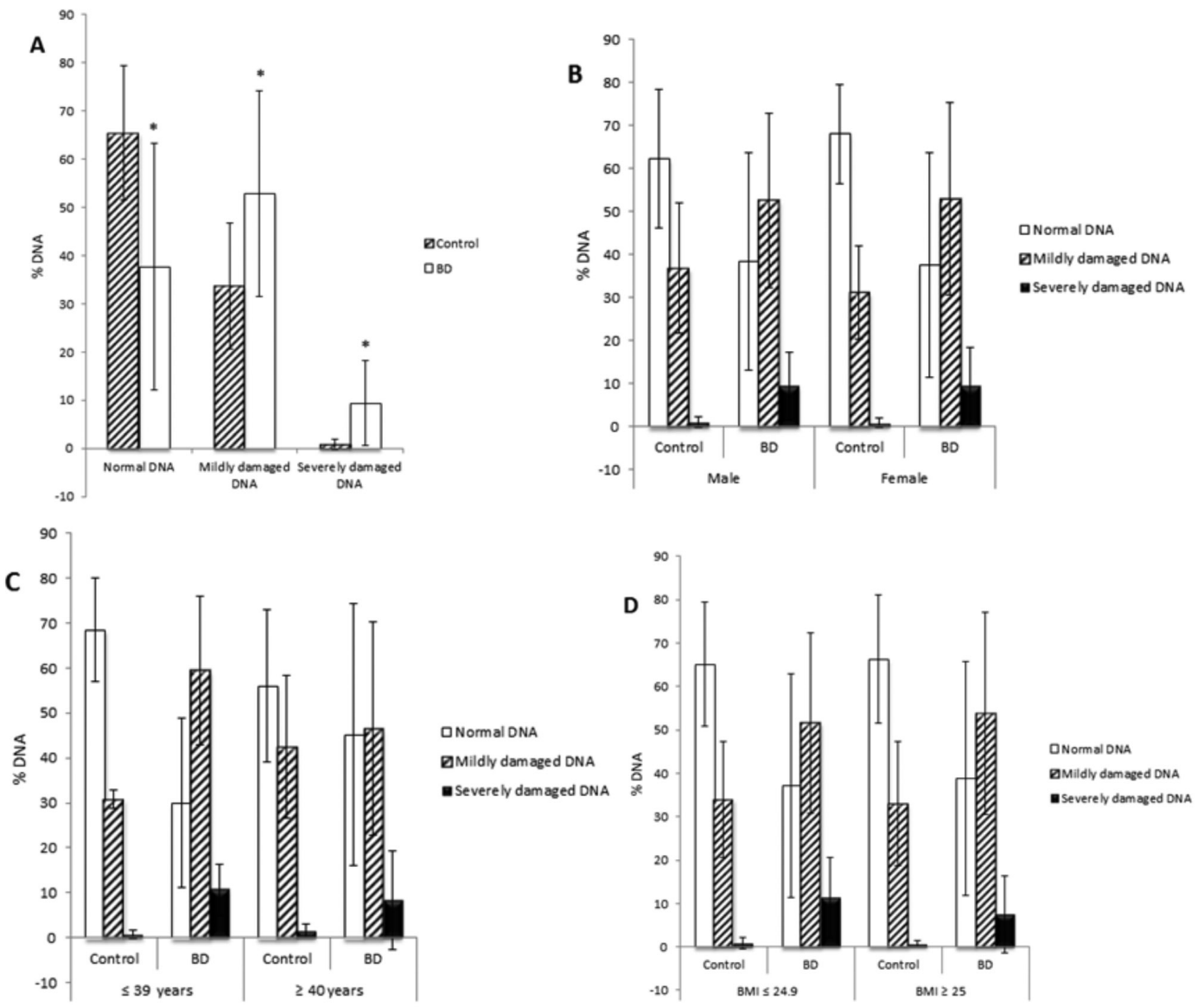

FIGURE 6. Percentage of DNA damage in BD patients and controls (A) Percentage of normal DNA was significantly higher in controls compared to $\mathrm{BD}(p<0.001)$, percentage of mildly damaged DNA was significantly higher in BD compared to controls $(p<0.001)$, percentage of severely damaged DNA was significantly higher in BD compared to controls $(p<0.001)$, (B) Percentage of DNA damages did not show significant difference when compared between BD and controls within a single gender as well as between males and female BD patients or controls, (C) Percentage of DNA damages did not show significant difference between $\mathrm{BD}$ and controls within a single age category as well as between BD patients aged $\leq 39$ years and $\geq 40$ years, (D) Percentage of DNA damages did not show significant differences between BD and controls grouped according to BMI $\leq 24.9$ and $\geq 25$

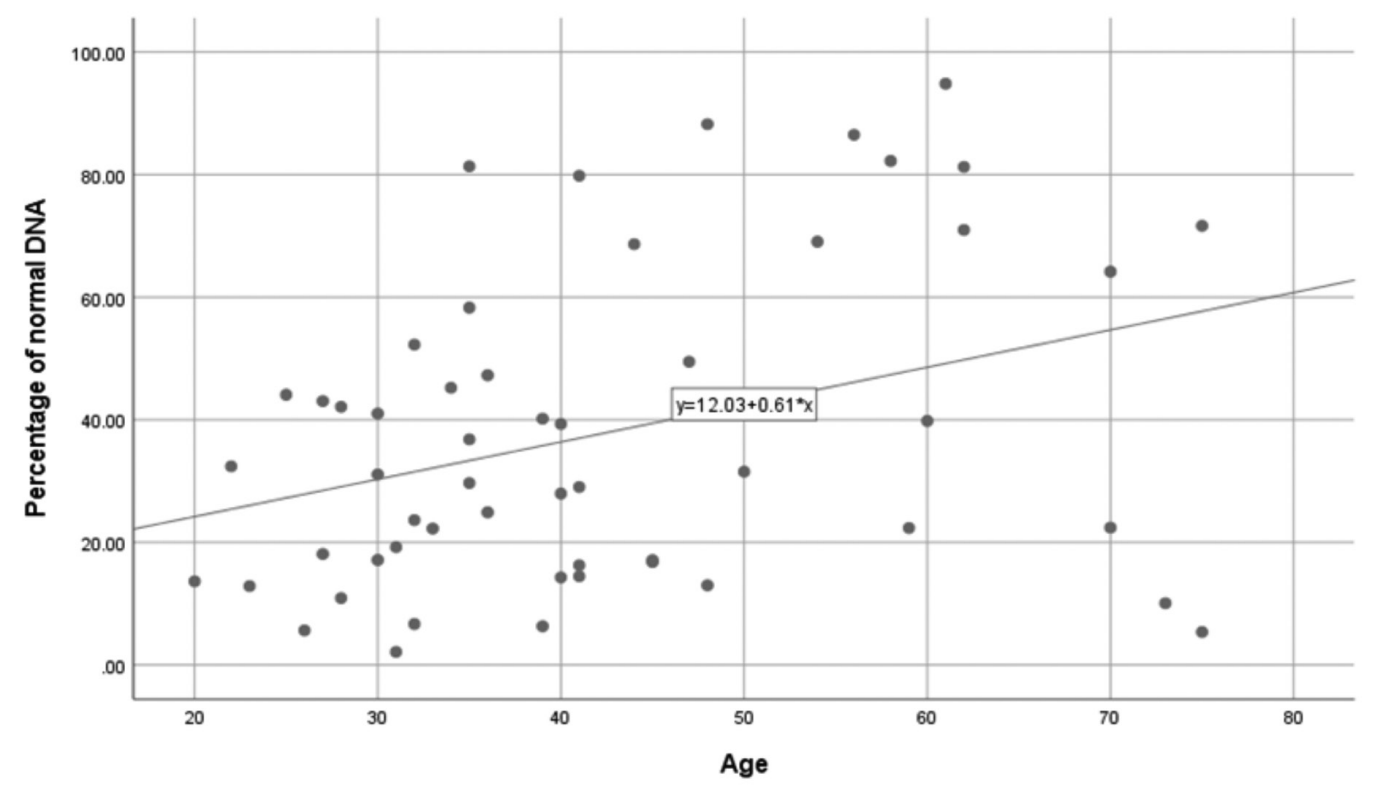

FIGURE 7. Percentage of normal DNA has positive correlation with age, $r=0.346$ 


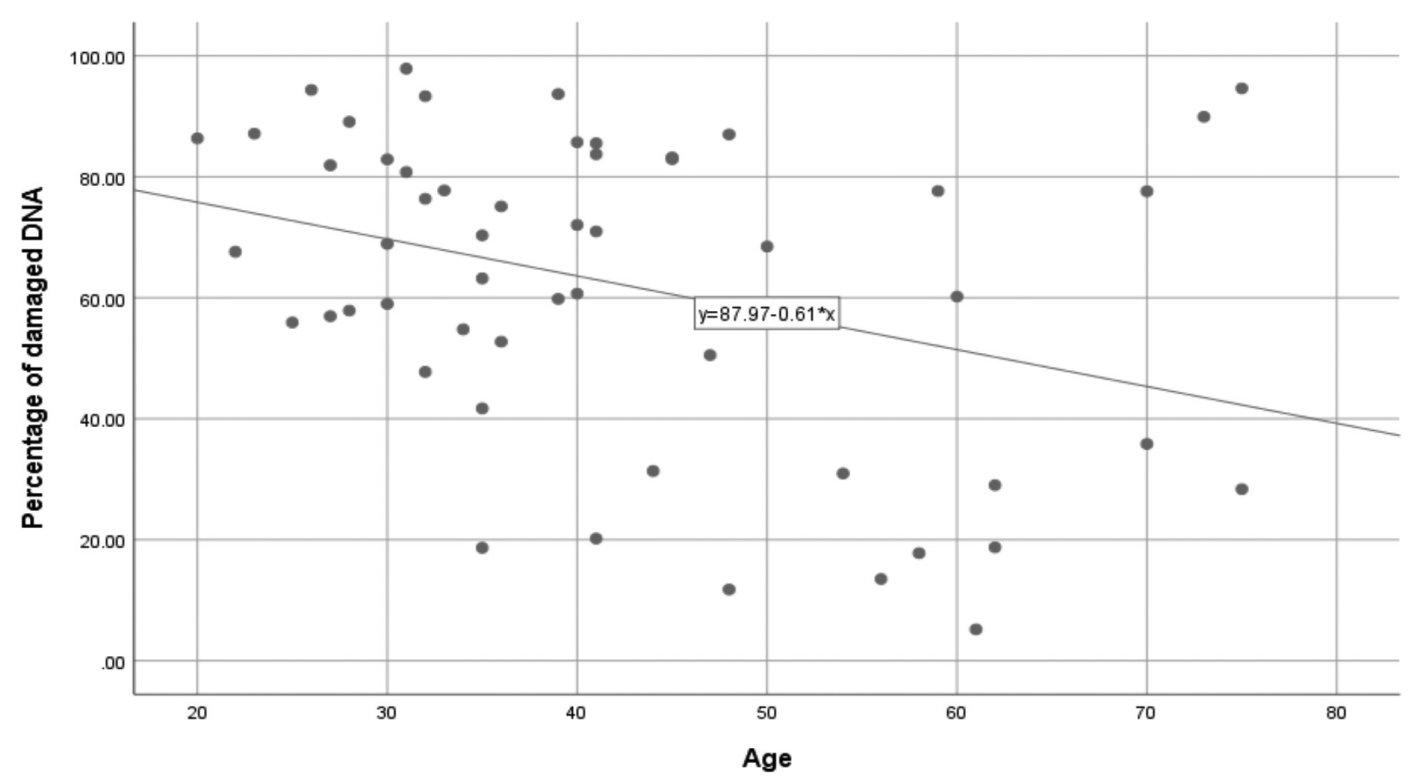

FIGURE 8. Percentage of damaged DNA has negative correlation with age, $r=-0.346$

radial diffusivity differences, could be explained by the variation in lipid hydroperoxide levels, indicating that peripheral lipid peroxidation levels were associated with white matter abnormalities.

In this study, DNA damage was also found to be markedly higher in BD compared to control. This is parallel with the findings from previous studies using similar methods (Andreazza et al. 2007; Frey et al. 2007). The effect of DNA damage in BD may be in concordance to the elevated morbidity and mortality risk due to general medical conditions such as obesity (Gao et al. 2004) and cardiovascular disease (Demirbag et al. 2005), since these conditions are more prevalent in $\mathrm{BD}$ compared to the general population (Kupfer 2005; Lopresti \& Drummond 2013). Thus, further analysis was performed to determine whether increased BMI has significant influence on oxidative status in BD compared to control.

BMI classification was used according to the recommendation by WHO. Because none of the subjects were underweight $(<18.5)$, the subjects were grouped to normal weight $(\leq 24.9)$ and overweight $(\geq 25)$. Based on the results, only SOD levels showed significant difference when compared between subjects with BMI $\leq 24.9$ and $\geq 25$. BD subjects with BMI $\geq 25$ had lower SOD activity compared to those with $\mathrm{BMI} \leq 24.9$. This result shows that excess weight in $\mathrm{BD}$ is associated with lower SOD activity. This is in line with previous findings which reported that overweight leads to depletion in antioxidant enzyme activity (Olusi 2002; Ozata et al. 2002).

To the best of our knowledge, there is limited study which evaluates oxidative stress in BD patients according to age. One study which examined oxidative stress in older patients with BD found that patients had higher measures of lipid peroxidation than controls but the two groups showed comparable results in protein nitration (3-nitrotyrosine, $3 \mathrm{NT}$ ), protein carbonylation (protein carbonyl, $\mathrm{PC}$ ) and sub- products of lipid peroxidation (4-hydroxynonenal, 4HNE) (Andreazza et al. 2015). In this study, MDA concentration was significantly higher in subjects aged $\geq 40$ compared to those aged $\leq 39$. This is similar to the results published by Gil et al. (2002) where they concluded that old age is associated with an increase in systemic oxidative stress.

According to a previous finding, the prevalence of $\mathrm{BD}$ is higher in women compared to men (Wiener et al. 2014). While no significant difference was found between genders in all the oxidative parameters examined in our study, conflicting results have been documented, where one reported that male subjects showed significantly higher peripheral markers of oxidative stress than women (Bengesser et al. 2015), while another reported that women are more susceptible to oxidative stress than men (Wiener et al. 2014). The inconclusive results may due to the difference in studied population, research design and analysis methods used.

Correlation study was also performed in this study to determine whether age and BMI affected MDA concentration and DNA damage in BD. Interestingly, the results showed that the percentage of normal DNA increases with age while percentage of damaged DNA decreases with age among BD subjects. Age at onset has been regarded as a proxy assessment of disease severity in psychiatric disorders, where an early age at onset exhibits more incompetence in cognition, social ability, brain ventricle sizes as well as clinical and behavioral presentation (Saetre et al. 2011). It has been noted that an increase in frequency of DNA damage in patients with BD compared to controls is correlated to the severity of depression and manic symptoms (Andreazza et al. 2007). Young people with early-stage BD was also found to have an increase in protein damage and this has been postulated to be an early indication of systemic toxicity (Magalhaes et al. 2012). Thus, the combination of early onset as well as 
severe psychiatric symptoms of the younger group during sampling in this study may have contributed to higher percentage of DNA damage compared to the group aged 40 and above. On the other hand, no significant correlation has been found on age and BMI with MDA concentration. However, this data is limited to the small sample size adopted in this study as well as unequal distribution of age and gender of subjects in BD and control groups. Further investigations involving larger sample size are necessary to illustrate the underlying mechanisms of oxidative stress pathways in the progression of $\mathrm{BD}$, as well as moderating the influence of gender, age and anthropometric parameters in $\mathrm{BD}$.

\section{CONCLUSION}

Our findings support the preliminary evidence of altered oxidative status in BD. Based on the results, age and BMI are found to be associated with the oxidative status of BD patients regardless of gender.

\section{ACKNOWLEDGEMENTS}

This research is funded by Universiti Kebangsaan Malaysia Research University Grant GUP-2014-048. We would like to thank our subjects for their dedication and support.

\section{REFERENCES}

Aebi, H. 1984. Catalase in vitro. Methods in Enzymology 105: 121-126.

Andreazza, A.C., Gildengers, A., Rajji, T.K., Zuzarte, P.M.L., Mulsant, B.H. \& Young, L.T. 2015. Oxidative stress in older patients with bipolar disorder. The American Journal of Geriatric Psychiatry: Official Journal of the American Association for Geriatric Psychiatry 23(3): 314-319.

Andreazza, A.C., Kauer-Sant'anna, M., Frey, B.N., Bond, D.J., Kapczinski, F., Young, L.T. \& Yatham, L.N. 2008. Oxidative stress markers in bipolar disorder: A meta-analysis. Journal of Affective Disorders 111(2): 135-144.

Andreazza, A.C., Frey, B.N., Erdtmann, B., Salvador, M., Rombaldi, F., Santin, A., Goncalves, C.A. \& Kapczinski, F. 2007. DNA damage in bipolar disorder. Psychiatry Research 153(1): 27-32

Banerjee, U., Dasgupta, A., Rout, J.K. \& Singh, O.P. 2012. Effects of lithium therapy on $\mathrm{Na}+-\mathrm{K}+$-atpase activity and lipid peroxidation in bipolar disorder. Prog. Neuropsychopharmacol. Biol. Psychiatry 37(1): 56-61.

Benedetti, A., Fagiolini, A., Casamassima, F., Mian, M.S., Adamovit, A., Musetti, L., Lattanzi, L. \& Cassano, G.B. 2007. Gender differences in bipolar disorder type 1: A 48week prospective follow-up of 72 patients treated in an italian tertiary care center. The Journal of Nervous and Mental Disease 195(1): 93-96.

Bengesser, S.A., Lackner, N., Birner, A., Fellendorf, F.T., Platzer, M., Mitteregger, A., Unterweger, R., Reininghaus, B., Mangge, H., Wallner-Liebmann, S.J., Zelzer, S., Fuchs, D., Mcintyre, R.S., Kapfhammer, H.P. \& Reininghaus, E.Z. 2015. Peripheral markers of oxidative stress and antioxidative defense in euthymia of bipolar disorder: Gender and obesity effects. Journal of Affective Disorders 172: 367-374.
Berk, M., Copolov, D.L., Dean, O., Lu, K., Jeavons, S., Schapkaitz, I., Anderson-Hunt, M. \& Bush, A.I. 2008. $\mathrm{N}$-acetylcysteine for depressive symptoms in bipolar disorder: A double-blind randomized placebo-controlled trial. Biological Psychiatry 64(6): 468-475.

Berk, M., Kapczinski, F., Andreazza, A., Dean, O., Giorlando, F., Maes, M., Yücel, M., Gama, C., Dodd, S. \& Dean, B. 2011. Pathways underlying neuroprogression in bipolar disorder: Focus on inflammation, oxidative stress and neurotrophic factors. Neuroscience \& Biobehavioral Reviews 35(3): 804-817.

Beyer, W.F. \& Fridovich, I. 1987. Assaying for superoxide dismutase activity: Some large consequences of minor changes in conditions. Analytical Biochemistry 161(2): 559-566.

Brown, N.C., Andreazza, A.C. \& Young, L.T. 2014. An updated meta-analysis of oxidative stress markers in bipolar disorder Psychiatry Research 218(1): 61-68.

Chin, S.F., Ibahim, J., Makpol, S., Abdul Hamid, N.A., Abdul Latiff, A., Zakaria, Z., Mazlan, M., Mohd Yusof, Y.A., Abdul Karim, A. \& Wan Ngah, W.Z. 2011. Tocotrienol rich fraction supplementation improved lipid profile and oxidative status in healthy older adults: A randomized controlled study. Nutrition \& Metabolism 8: 42.

Chin, S.F., Hamid, N.A., Latiff, A.A., Zakaria, Z., Mazlan, M., Mohd Yusof, Y.A., Abdul Karim, A., Ibahim, J., Hamid, Z. \& Wan Ngah, W.Z. 2008. Reduction of DNA damage in older healthy adults by Tri E Tocotrienol supplementation. Nutrition 24(1): 1-10.

Choy, K.H., Dean, O., Berk, M., Bush, A.I. \& van den Buuse, M. 2010. Effects of N-acety-lcysteine treatment on glutathione depletion and a short-term spatial memory defcit in 2-cyclohexene-1-one-treated rats. European Journal of Pharmacology 649(1-3): 224-228.

De Sousa, R.T., Zarate, C.A., Zanetti, M.V., Costa, A.C., Talib, L.L., Gattaz, W.F. \& Machado-Vieira, R. 2014. Oxidative stress in early stage bipolar disorder and the association with response to lithium. Journal of Psychiatric Research 50: $36-41$.

Dean, O., Bush, A.I., Berk, M., Copolov, D.L. \& van den Buuse, M. 2009. Glutathione depletion in the brain disrupts short-term spatial memory in the Y-maze in rats and mice. Behavioural Brain Research 198(1): 258-262.

Demirbag, R., Yilmaz, R. \& Kocyigit, A. 2005. Relationship between DNA damage, total antioxidant capacity and coronary artery disease. Mutatation Research 570(2): 197 203.

Diflorio, A. \& Jones, I. 2010. Is sex important? Gender differences in bipolar disorder. International Review of Psychiatry 22(5): 437-452.

Dröge, W. 2002. Free radicals in the physiological control of cell function. Physiological Reviews 82: 47-95.

Elhaik, E. \& Zandi, P. 2015. Dysregulation of the Nf-Kb pathway as a potential inducer of bipolar disorder. Journal of Psychiatric Research 70: 18-27.

Fernandes, B.S., Gama, C.S., Maria Ceresér, K., Yatham, L.N., Fries, G.R., Colpo, G., De Lucena, D., Kunz, M., Gomes, F.A. \& Kapczinski, F. 2011. Brain-derived neurotrophic factor as a state-marker of mood episodes in bipolar disorders: A systematic review and meta-regression analysis. Journal of Psychiatric Research 45(8): 995-1004.

Frey, B.N., Andreazza, A.C., Houenou, J., Jamain, S., Goldstein, B.I., Frye, M.A., Leboyer, M., Berk, M., Malhi, G.S. \& 
Lopez-Jaramillo, C. 2013. Biomarkers in bipolar disorder: A positional paper from the international society for bipolar disorders biomarkers task force. Australian and New Zealand Journal of Psychiatry 47(4): 321-332.

Frey, B.N., Andreazza, A.C., Kunz, M., Gomes, F.A., Quevedo, J., Salvador, M., Gonçalves, C.A. \& Kapczinski, F. 2007. Increased oxidative stress and DNA damage in bipolar disorder: A twin-case report. Progress in NeuroPsychopharmacology \& Biological Psychiatry 31(1): 283285.

Gao, D., Wei, C., Chen, L., Huang, J., Yang, S. \& Diehl, A.M. 2004. Oxidative DNA damage and DNA repair enzyme expression are inversely related in murine models of fatty liver disease. American Journal of Physiology Gastrointestinal \& Liver Physiology 287(5): G1070-G1077.

Gil, P., Fariñas, F., Casado, A. \& López-Fernández, E. 2002. Malondialdehyde: A possible marker of ageing. Gerontology 48(4): 209-214.

Góth, L. \& Nagy, T. 2013. Inherited catalase deficiency: Is it benign or a factor in various age related disorders? Mutation Research 753(2): 147-154.

Grande, I., Magalhaes, P.V., Kunz, M., Vieta, E. \& Kapczinski, F. 2012. Mediators of allostasis and systemic toxicity in bipolar disorder. Physiology \& Behaviour 106(1): 46-50.

Haouala, A.B., Amamou, B., Allègue, M., Zaafrane, F. \& Gaha, F. 2016. Age at onset of bipolar disorders: Clinical implication and prognosis of early and late onset. European Neuropsychopharmacology 26: S429.

Ighodaro, O.M. \& Akinloye, O.A. 2017. First line defence antioxidants-superoxide dismutase (SOD), catalase (CAT) and glutathione peroxidase (GPX): Their fundamental role in the entire antioxidant defence grid. Alexandria Journal of Medicine 54(4): 287-293.

Kapczinski, F., Dal-Pizzol, F., Teixeira, A.L., Magalhaes, P.V., Kauer-Sant'anna, M., Klamt, F., Moreira, J.C., De Bittencourt Pasquali, M.A., Fries, G.R., Quevedo, J., Gama, C.S. \& Post, R. 2011. Peripheral biomarkers and illness activity in bipolar disorder. Journal of Psychiatric Research 45(2): 156-161.

Kawa, I., Carter, J.D., Joyce, P.R., Doughty, C.J., Frampton, C.M., Elisabeth Wells, J., Walsh, A.E. \& Olds, R.J. 2005. Gender differences in bipolar disorder: Age of onset, course, comorbidity, and symptom presentation. Bipolar Disorders 7(2): 119-125.

Kessing, L.V. 2004. Gender differences in the phenomenology of bipolar disorder. Bipolar Disorders 6(5): 421-425.

Kessler, R.C., Mcgonagle, K.A., Swartz, M., Blazer, D.G. \& Nelson, C.B. 1993. Sex and depression in the national comorbidity survey I: Lifetime prevalence, chronicity and recurrence. Journal of Affective Disorders 29(2-3): 85-96.

Kim, G.H., Kim, J.E., Rhie, S.J. \& Yoon, S. 2015. The role of oxidative stress in neurodegenerative diseases. Experimental Neurobiology 24(4): 325-340.

Kraepelin, E. 1921. Manic depressive insanity and paranoia. The Journal of Nervous \& Mental Disease 53(4): 350.

Kuloglu, M., Ustundag, B., Atmaca, M., Canatan, H., Tezcan, A.E. \& Cinkilinc, N. 2002. Lipid peroxidation and antioxidant enzyme levels in patients with schizophrenia and bipolar disorder. Cell Biochemistry \& Function 20(2): 171-175.

Kunz, M., Gama, C.S., Andreazza, A.C., Salvador, M., Ceresér, K.M., Gomes, F.A., Belmonte-De-Abreu, P.S., Berk, M. \& Kapczinski, F. 2008. Elevated serum superoxide dismutase and thiobarbituric acid reactive substances in different phases of bipolar disorder and in schizophrenia. Progress in Neuro-Psychopharmacology \& Biological Psychiatry 32(7): 1677-1681.

Kupfer, D.J. 2005. The increasing medical burden in bipolar disorder. JAMA 293(20): 2528-2530.

Laursen, T.M. 2011. Life expectancy among persons with schizophrenia or bipolar affective disorder. Schizophrenia Research 131(1-3): 101-104.

Lewis, P., Stefanovic, N., Pete, J., Calkin, A.C., Giunti, S., Thallas-Bonke, V., Jandeleit-Dahm, K.A., Allen, T.J., Kola, I., Cooper, M.E. \& de Haan, J.B. 2007. Lack of the antioxidant enzyme glutathione peroxidase-1 accelerates atherosclerosis in diabetic apolipoprotein E-Deficient mice. Circulation 115: 2178-2187.

Lopresti, A.L. \& Drummond, P.D. 2013. Obesity and psychiatric disorders: Commonalities in dysregulated biological pathways and their implications for treatment. Progress in Neuro-Psychopharmacology \& Biological Psychiatry 45: 92-99.

Magalhaes, P.V., Jansen, K., Pinheiro, R.T., Colpo, G.D., Da Motta, L.L., Klamt, F., Da Silva, R.A. \& Kapczinski, F. 2012. Peripheral oxidative damage in early-stage mood disorders: A nested population-based case-control study. International Journal of Neuropsychopharmacology 15(8): 1043-1050.

Mahadik, S.P., Evans, D. \& Lal, H. 2001. Oxidative stress and role of antioxidant and $\Omega-3$ essential fatty acid supplementation in schizophrenia. Progress in Neuro-Psychopharmacology \& Biological Psychiatry 25(3): 463-493.

Malaysian Psychiatric Association, M.P.A. 2007. Malaysian Consensus Statement for the Treatment of Bipolar Disorder.

Malorni, W., Campesi, I., Straface, E., Vella, S. \& Franconi, F. 2007. Redox features of the cell: A gender perspective. Antioxidants \& Redox Signaling 9(11): 1779-1802.

Mcglashan, T.H. 1988. Adolescent versus adult onset of mania. American Journal of Psychiatry 145(2): 221-223.

Merikangas, K.R., Jin, R., He, J.P., Kessler, R.C., Lee, S., Sampson, N.A., Viana, M.C., Andrade, L.H., Hu, C., Karam, E.G., Ladea, M., Medina-Mora, M.E., Ono, Y., Posada-Villa, J., Sagar, R., Wells, J.E. \& Zarkov, Z. 2011. Prevalence and correlates of bipolar spectrum disorder in the world mental health survey initiative. Archives of General Psychiatry 68(3): 241-251.

Merikangas, K.R., Akiskal, H.S., Angst, J., Greenberg, P.E., Hirschfeld, R.M., Petukhova, M. \& Kessler, R.C. 2007. Lifetime and 12-month prevalence of bipolar spectrum disorder in the national comorbidity survey replication. Archives of General Psychiatry 64(5): 543-552.

Miquel, L., Roncero, C., Lopez-Ortiz, C. \& Casas, M. 2011. Epidemiological and diagnostic axis i gender differences in dual diagnosis patients. Adicciones 23(2): 165-172.

Nivoli, A.M.A., Pacchiarotti, I., Rosa, A.R., Popovic, D., Murru, A., Valenti, M., Bonnin, C.M., Grande, I., Sanchez-Moreno, J., Vieta, E. \& Colom, F. 2011. Gender differences in a cohort study of 604 bipolar patients: The role of predominant polarity. Journal of Affective Disorders 133(3): 443-449.

O’brien, S.M., Scully, P., Scott, L.V. \& Dinan, T.G. 2006. Cytokine profiles in bipolar affective disorder: Focus on acutely ill patients. Journal of Affective Disorders 90(2): 263-267.

Olusi, S. 2002. Obesity is an independent risk factor for plasma lipid peroxidation and depletion of erythrocyte cytoprotectic enzymes in humans. International Journal of Obesity 26(9): 1159-1164. 
Ozata, M., Mergen, M., Oktenli, C., Aydin, A., Sanisoglu, S.Y., Bolu, E., Yilmaz, M.I., Sayal, A., Isimer, A. \& Ozdemir, I.C. 2002. Increased oxidative stress and hypozincemia in male obesity. Clinical Biochemistry 35(8): 627-631.

Ozcan, M.E., Gulec, M., Ozerol, E., Polat, R. \& Akyol, O. 2004. Antioxidant enzyme activities and oxidative stress in affective disorders. International Clinical Psychopharmacology 19(2): 89-95.

Paglia, D.E. \& Valentine, W.N. 1967. Studies on the quantitative and qualitative characterization of erythrocyte glutathione peroxidase. Journal of Laboratory \& Clinical Medicine 70(1): 158-169.

Pilz, J., Meineke, I. \& Gleiter, C. 2000. Measurement of free and bound malondialdehyde in plasma by high-performance liquid chromatography as the 2,4-dinitrophenylhydrazine derivative. Journal of Chromatography B: Biomedical Sciences \& Applications 742(2): 315-325.

Ranjekar, P.K., Hinge, A., Hegde, M.V., Ghate, M., Kale, A., Sitasawad, S., Wagh, U.V., Debsikdar, V.B. \& Mahadik, S.P. 2003. Decreased antioxidant enzymes and membrane essential polyunsaturated fatty acids in schizophrenic and bipolar mood disorder patients. Psychiatry Research 121(2): 109-122.

Ringen, P., Lagerberg, T., Birkenaes, A., Engn, J., Faerden, A., Jonsdottir, H., Nesvåg, R., Friis, S., Opjordsmoen, S. \& Larsen, F. 2008. Differences in prevalence and patterns of substance use in schizophrenia and bipolar disorder. Psychological Medicine 38(09): 1241-1249.

Rosa, A.R., Singh, N., Whitaker, E., de Brito, M., Lewis, A.M., Vieta, E., Churchill, G.C., Geddes, J.R. \& Goodwin, G.M. 2014. Altered plasma glutathione levels in bipolar disorder indicates higher oxidative stress; A possible risk factor for illness onset despite normal brain-derived neurotrophic factor (BDNF) levels. Psychological Medicine 4(11): 2409-2418.

Roshanaei-Moghaddam, B. \& Katon, W. 2009. Premature mortality from general medical illnesses among persons with bipolar disorder: A review. Psychiatric Services 60(2): 147-156.

Saetre, P., Vares, M., Werge, T., Andreassen, O.A., Arinami, T., Ishiguro, H., Nanko, S., Tan, E.C., Han, D.H. \& Roffman, J.L. 2011. Methylenetetrahydrofolate reductase (Mthfr) C677t and A1298c polymorphisms and age of onset in schizophrenia: A combined analysis of independent samples. American Journal of Medical Genetics Part B: Neuropsychiatric Genetics 156(2): 215-224.

Sarangarajan, R., Meera, S., Rukkumani, R., Sankar, P. \& Anuradha, G. 2017. Antioxidants: Friend or foe? Asian Pacific Journal of Tropical Medicine 10(12): 1111-1116.

Savas, H.A., Gergerlioglu, H.S., Armutcu, F., Herken, H., Yilmaz, H.R., Kocoglu, E., Selek, S., Tutkun, H., Zoroglu, S.S. \& Akyol, O. 2006. Elevated serum nitric oxide and superoxide dismutase in euthymic bipolar patients: Impact of past episodes. The World Journal of Biological Psychiatry 7(1): 51-55.
Selek, S., Savas, H.A., Gergerlioglu, H.S., Bulbul, F., Uz, E. \& Yumru, M. 2008. The course of nitric oxide and superoxide dismutase during treatment of bipolar depressive episode. Journal of Affective Disorders 107(1-3): 89-94.

Singh, N., Stephens, R. \& Schneider, E. 1994. Modifications of alkaline microgel electrophoresis for sensitive detection of DNA damage. International Journal of Radiation Biology 66(1): 23-28.

Swartz, H.A. \& Fagiolini, A. 2012. Cardiovascular disease and bipolar disorder: Risk and clinical implications. Journal of Clinical Psychiatry 73(12): 1563-1565.

Uher, R. 2014. Gene-environment interactions in severe mental illness. Frontiers in Psychiatry 5: 48.

Van Vliet, I.M. \& De Beurs, E. 2007. The MINI-international neuropsychiatric interview. A brief structured diagnostic psychiatric interview for DSM-IV en ICD-10 psychiatric disorders. Tijdschrift voor Psychiatrie 49(6): 393-397.

Versace, A., Andreazza, A.C., Young, L., Fournier, J.C., Almeida, J.R., Stiffler, R.S., Lockovich, J.C., Aslam, H.A., Pollock, M.H. \& Park, H. 2014. Elevated serum measures of lipid peroxidation and abnormal prefrontal white matter in euthymic bipolar adults: Toward peripheral biomarkers of bipolar disorder. Molecular Psychiatry 19(2): 200-208.

Wiener, C., Rassier, G.T., Kaster, M.P., Jansen, K., Pinheiro, R.T., Klamt, F., Magalhães, P.V., Kapczinski, F., Ghisleni, G. \& Da Silva, R.A. 2014. Gender-based differences in oxidative stress parameters do not underlie the differences in mood disorders susceptibility between sexes. European Psychiatry 29(1): 58-63.

Department of Biochemistry

Faculty of Medicine

Universiti Kebangsaan Malaysia Medical Center

Jalan Yaacob Latif, Bandar Tun Razak

56000 Cheras, Kuala Lumpur, Federal Territory

Malaysia

*Corresponding author; email: joaan@ukm.edu.my

Received: 23 August 2017

Accepted: 25 September 2018 